\title{
Biochemical Response of Mungbean [Vigna radiata (L.) Wilczek] Genotypes under Terminal Heat Stress at Reproductive Stage
}

\author{
G. Chand ${ }^{1}$, A. S. Nandwal ${ }^{2}$, S. Dogra ${ }^{1}$ and M. Sharma ${ }^{1}$ \\ ${ }^{1}$ Division of Plant Physiology FBSc SKUAST Jammu \\ ${ }^{2}$ Department of Botany and Plant Physiology, CCS Haryana Agricultural University, Hisar- \\ 125004, Haryana, India \\ *Corresponding author
}

\section{A B S T R A C T}

The investigation was conducted on three mungbean [Vigna radiata (L.) Wilczek] genotypes namely MH-421, MH-318 and Basanti genotypes to study

\section{Keywords}

Mungbean, Relative water content,

Proline, Yield,

Total soluble

carbohydrates

Article Info

Accepted:

22 June 2020

Available Online:

10 July 2020 their biochemical, and yield response in relation to terminal heat stress tolerance. The plants were raised in earthen pots $(30 \mathrm{~cm}$ diameter $)$ filled with $5.5 \mathrm{~kg}$ of dune sand (Typic Torrispamments) under screen house conditions. High temperature stress was given by manipulation of sowing dates i.e. normal sown (12 $2^{\text {th }}$ March, 2013) and late sown (29 $9^{\text {th }}$ March, 2013). The sampling was done at 3 and 7 days after exposure (DAE) to $>35^{\circ} \mathrm{C}$ temperature and the control readings were taken at the temperature below $<35^{\circ} \mathrm{C}$ at reproductive stage. High temperature resulted in decreased water potential relative water content, relative stress injury and yield but increase in proline content, total soluble carbohydrates and lipid peroxidation Sensitive genotypes showed large reductions in aforementioned physiological traits. On the other hand, tolerant genotype ( $\mathrm{MH} \mathrm{421)}$ maintained higher proline, total soluble content, relative stress injury and yield. After 7 days of exposure to high temperature under late sown, above parameters and yield losses in most sensitive genotypes MH 318 and Basanti.

\section{Introduction}

Mungbean [Vigna radiata (L.) Wilczek] is a short duration, warm season legume crop Northern region of India.India is the largest producer and consumer of mungbean and accounts for about $65 \%$ of the average and $54 \%$ of the world production of this crop
(Lambridg et al., 2007). It is the third most important pulse crop in India, occupying nearly 3.72 million ha area with 1.56 million tons production with productivity $512 \mathrm{~kg} \mathrm{ha}^{-1}$ (Ali et al., 2012). Whereas Haryana, the approximate values are 0.712 million ha, 0.341 million tonnes and $534 \mathrm{~kg} \mathrm{ha}^{-1}$ respectively. Mungbean is a main protein 
source for the vegetarian diet. Mungbean may also be sown as an inter crop or as a green manure or cover crop. It fetches high price in the market and is a preferred pulse crop for the farmers (Kumar et al., 2011; Mansoor and Naqvi 2013).

Heat stress can cause several alterations at cellular and sub-cellular levels and the response of the plants depends upon the growth stage, intensity, and duration of the exposure to heat stress (Karim et al., 2003; Sung et al., 2003; Mansoor and Naqvi, 2013). The direct effects of heat stress include denaturation of proteins and enzymes (Kepova et al., 2005), damage to membranes while its indirect effects may include inactivation of enzymes present in the mitochondria and chloroplasts, impaired protein synthesis, degradation of proteins, and disruption of membrane integrity (Karim et al., 2003; Howarth 2005; Kumar et al., 2011). Accumulation of total soluble sugars (TSS) under heat stress has been implicated in the establishment and maintenane of thermotolerance (Rizhsky et al., 2004; Wahid and Close 2007). Sugars serve as signalling molecules during abiotic stress in stresstolerant phenotypes (Rosa et al., 2009). Sugar signaling pathways interact with stress pathways in a complex network to modulate the metabolic responses of plants (Gill et al., 2003). Starch metabolism is very sensitive to abiotic stresses generally leads to a depletion of starch content and to the accumulation of soluble sugars in leaves (Kaplan and Guy 2004; Basu et al., 2007; Kempa et al., 2008). Heat stress causes increased membrane damage due to lipid peroxidation (Amirjani 2012). Lipid peroxidation is a natural metabolic process under normal aerobic conditions and it is one of the most investigated consequences of ROS action on membrane structure and function (Blokhina et $a l .$, 2003). Lipid peroxidation is a commonly utilized stress indicator of membrane damage.
Heat stress impairs mitochondrial functions thereby resulting in the induction of oxidative damage that manifests in lipid peroxidation, detected by malondi-aldehyde (MDA) content (Larkindale and Knight 2002; Vacca et al., 2004).

High temperature during the reproductive stage in chickpea is a major cause of yield loss by reducing pod formation and seed set (Paulsen 1994; Wang et al., 2006; Basu et al., 2009; Kumar et al., 2012; Thangwana and Ogola 2012). Devasirvatham et al., (2010) found that pollen sterility is one of the reasons for lower pod set during pre-anthesis high temperature stress. Recently, heat tolerant genotypes were identified from field screening in India (Krishnamurthy et al., 2011; Upadhyaya et al., 2011). Poor pod set and grain yield in chickpea can result from the high temperature stress during pre-and/or post-anthesis development. The negative effect of high temperature on grain yield is expected to increase due to global warming. A minimum decrease of $53 \mathrm{~kg} / \mathrm{ha}$ of chickpea yield was observed in India per $1{ }^{\circ} \mathrm{C}$ increase in seasonal temperature (Kalra et al., 2008).

\section{Materials and Methods}

\section{Plant material and growth condition}

In this study Mungbean genotypes namely $\mathrm{MH}$ - 421, $\mathrm{MH}-318$, and Basanti were raised in earthen pots $(30 \mathrm{~cm}$ diameter $)$ filled with $5.5 \mathrm{~kg}$ of dune sand (Typic Torrispamments) under screen house conditions. Before sowing, the seeds were surface sterilized with $0.1 \% \mathrm{HgCl}_{2}$ for two minutes and washed with distilled water twice. Then seeds were inoculated with culture (Rhizobium leguminosarum, S-24). After thinning two plants were retained in each pot. Nitrogen free nutrient solution (Wilson and Reisenauer 1963) was given at required time intervals. 


\section{Heat stress imposition}

Destructive sampling will be done at 3 to 7days (DAT) after the plants experiencing temperature above $35^{\circ} \mathrm{C}$.

\section{Water potential $(\Psi w)$ of leaf}

Water potential of leaf was measured with the help of Pressure Chamber (Model 3005, Soil Moisture Equipment Corporation, Santa Barbara, CA, USA) between 8 AM to 10 AM.

\section{Relative water content (RWC \%) of leaf}

The RWC was calculated using the formula (Weatherley, 1950).

\section{The relative stress injury (RSI \%)}

The relative stress injury (RSI \%) in leaves was evaluated by (Sullivan 1972). The relative stress injury (RSI) was calculated as follows: $\operatorname{RSI}(\%)=1-\mathrm{EC}_{\mathrm{a}} / \mathrm{EC}_{\mathrm{b}} \times 100$.

\section{Biochemical analysis}

\section{Proline content}

Proline content was estimated by using the method of Bates et al., (1973). Standard curve was prepared by using graded concentration of proline in $3 \%$ sulphosalicylic acid. The proline content was expressed as $\mu \mathrm{mol} \mathrm{g}^{-1}$ FW.

\section{Total soluble carbohydrates}

Total soluble carbohydrates were determined with the method of Yemm and Willis (1954) using anthrone reagent. Standard curve was prepared using graded concentration of $\mathrm{D}$ glucose and the data were expressed as g FW $\mathrm{g}-1$. The equation of the standard curve was $\mathrm{y}$ $=1.222 \mathrm{x}-0.001, \mathrm{R}^{2}=0.9944$.
The level of lipid peroxidation was measured in terms of malondialdehyde (MDA) present in leaf tissues. MDA is a product of lipid peroxidation and was measured by thiobarbituric acid (TBA) reaction with minor modifications of the method of Heath and Packer (1968).

\section{The Heat Susceptibility Index (HSI)}

It was estimated for seed yield using the formula suggested by Fischer and Maurer (1978).

$\mathrm{HSI}=\frac{1-[\mathrm{YL} / \mathrm{YN}]}{1-[\mathrm{XL} / \mathrm{XN}]}$

Where, $\mathrm{YL}=$ Mean seed yield of a genotype under late sown condition

$\mathrm{YN}=$ Mean seed yield of a genotype under normal sown condition

$\mathrm{XL}=$ Mean seed yield of all genotype under late sown condition

$\mathrm{XN}=$ Mean seed yield of all genotype under normal sown condition

\section{The yield stability ratio (YS)}

Total soluble carbohydrates was calculated as per Lewis (1954).

YS $=\frac{\text { Seed yield under late sown condition }}{\text { Seed yield under normal sown condition }} \times 100$

\section{Statistical analysis}

For each parameter, three pots having three plants per pot were sampled at a time which comprises of three replicates. Data were analyzed using Completely Randomized Block Design (CRBD) for two factors. 
Treatments were compared using critical difference $(\mathrm{CD})$ at $5 \%$ level of significance. Data were subjected to analysis of variance (ANOVA) using Online Statistical Analysis Package (OPSTAT, Computer Section, CCS Haryana Agricultural University, Hisar 125 004, Haryana, India).

\section{Results and Discussion}

\section{Plant water status}

\section{Water potential $\left(\psi_{\mathrm{w}}\right)$ of leaf}

With the increase in period of DAE to high temperature $\left(>35^{\circ} \mathrm{C}\right)$ a significant decline in $\psi_{\mathrm{w}}(-\mathrm{MPa})$ of leaves was observed in all three genotypes, the mean values of leaf water potential were $-0.45,-0.92$ and -1.71 at control, 3, and 7 DAE, respectively (Table 1). In normal sown genotype MH 421 (-1.14) showed more negative values followed by MH 318 (-1.01) and Basanti (-0.93). Under late sown condition leaf water potential $\left(\psi_{\mathrm{w}}\right)$ followed the same trend as in normal sown condition and genotype MH 421 showed highest negative values of $\psi_{\mathrm{w}}(-1.59)$.

\section{Relative water content (RWC \%) of leaf}

Table 2 showed that mean values of RWC of leaves in all three mungbean genotypes significantly decreased from $74.55 \%$ to $56.69 \%$ with increasing the period of DAE to high temperature $\left(>35^{\circ} \mathrm{C}\right)$ from control to 7 DAE. Maximum RWC was noticed in $\mathrm{MH}$ $421(72.40 \%)$ followed by MH 318 (66.51\%) and minimum in Basanti $(62.90 \%)$ in normal sown and significantly decreased from $73.65 \%$ to $63.41 \%$ with increasing the period of DAE to high temperature $\left(>35^{\circ} \mathrm{C}\right)$ from control to 7 DAE. Maximum RWC was noticed in $\mathrm{MH} 421$ (70.35\%) at par with $\mathrm{MH}$ $318(70.34 \%)$ and minimum in Basanti $(65.22 \%)$ in late sown.

\section{Relative stress injury (RSI \%) (Membrane stability) of leaf}

Data presented in Table 3 shows the effect of high temperature $\left(>35^{\circ} \mathrm{C}\right)$ on leaf membrane stability of mungbean genotypes. RSI increased significantly with increase in DAE to high temperature in all three genotypes i.e. from 21.40 to $34.69 \%$. The maximum increase in RSI (32.17 to $41.34 \%$ ) was observed in Basanti followed by MH 318 (29.24 to $40.72 \%$ ) and minimum was noticed in MH 421 (26.80 to 34.88\%).

\section{Biochemical studies}

\section{Proline content}

The data showed significant differences in proline content of leaves and it increased from 3.11 to 17.77 with increased DAE to high temperature (Fig. 1). The highest proline content (19.83) was observed in MH 421 followed by $\mathrm{MH} 318$ (17.57) and lowest in Basanti (15.91) at 7 DAE as compared to control under normal sown. Whereas under late sown it increased from 4.06 to 23.72 with increased DAE to high temperature. The highest proline content (25.21) was observed in $\mathrm{MH} 421$ followed by $\mathrm{MH} 318$ (23.75) and lowest was in Basanti (22.19) at 7 DAE as compared to control.

\section{Total soluble carbohydrates (TSC)}

The changes in the levels of TSC with increasing DAE to high temperature in leaves of mungbean genotypes are shown in Fig. 2. The TSC increased significantly with every increment of exposed day to high temperature $\left(>35^{\circ} \mathrm{C}\right)$ i.e. from 23.58 to 33.65 . The genotype MH 421 maintained higher (31.85) TSC followed by MH 318 (27.20) and minimum in Basanti (26.56) in normal sown. Similarly, in late sown the TSC increased i.e. from 24.49 to 35.15 . The genotype MH 421 
maintained higher (33.38) TSC followed by MH 318 (30.08) and minimum in Basanti (28.26).

\section{Lipid Peroxidation}

Lipid peroxidation was measured in terms of malondialdehyde (MDA) content. MDA content showed increasing trend from 21.75 to 34.44 with the increased DAE to high temperature $\left(>35^{\circ} \mathrm{C}\right)$ in all genotypes. Fig. 3 showed that the maximum MDA content was measured in Basanti (30.66) as compared to MH 318 (28.97) and minimum in MH 421 (28.26) under normal sown. In late sown also the maximum MDA content was measured in Basanti (35.84) as compared to $\mathrm{MH} 318$ (34.81) and minimum in MH 421 (29.60).

\section{Seed yield plant ${ }^{-1}$}

The mean seed yield plant $^{-1}$ of late sown treatment was less than the mean seed yield of normal sown due to high temperature $\left(>35^{\circ} \mathrm{C}\right)$ i.e. it was $2.86 \mathrm{~g}$ per plant in normal sown, while it was $1.93 \mathrm{~g}$ in late sown (Table 4). The genotypes showed significant differences for seed yield in both normal and late sown experiments. The mean seed yield was highest in $\mathrm{MH} 421(3.11 \mathrm{~g})$ compared to $\mathrm{MH}$ 318(2.21) and Basanti (1.86 g). The maximum reduction in seed yield was found in Basanti (44.4\%) followed by $\mathrm{MH} 318(36.7 \%)$ and minimum in $\mathrm{MH} 421$ (21.5\%). The overall interaction values were statistically significant for test weight in both normal and late sown experiments

\section{Heat Susceptibility Index (HSI) and yield stability (YS \%)}

The HSI and YS were calculated for both genotypes (Table 4). The mean HSI value was low while YS value was high in MH 421 i.e. 0.66 and 78.51 , respectively. In genotype $\mathrm{MH}$ 318 their values were 1.16 and 63.33 and in genotype Basanti were 1.38 and 55.64, respectively. The results were statistically significant for yield plant ${ }^{-1}$.

Table.1 Changes in water potential $\left(\psi_{\mathrm{w}}\right)$ of leaves in mungbean genotypes when exposed to high temperature

\begin{tabular}{|c|c|c|c|c|c|c|c|c|}
\hline \multirow[t]{4}{*}{ Genotypes } & \multicolumn{8}{|c|}{$\psi_{\mathbf{w}}(-\mathbf{M P a})$} \\
\hline & \multicolumn{4}{|c|}{ Normal sown } & \multicolumn{4}{|c|}{ Late sown } \\
\hline & \multirow{2}{*}{$\begin{array}{c}\text { Control } \\
<35^{\circ}\end{array}$} & \multicolumn{3}{|c|}{$\begin{array}{c}>35^{\circ} \mathrm{C} \\
\text { Days of exposure (DAE) }\end{array}$} & \multicolumn{4}{|c|}{$\begin{array}{c}>35^{\circ} \mathrm{C} \\
\text { Days of exposure (DAE) }\end{array}$} \\
\hline & & 3 & 7 & Mean & Control & 3 & 7 & Mean \\
\hline MH 421 & -0.54 & -1.09 & -1.79 & -1.14 & -0.74 & -1.80 & -1.96 & -1.59 \\
\hline MH 318 & -0.43 & -0.89 & -1.69 & -1.01 & -0.69 & -1.78 & -1.96 & -1.48 \\
\hline Basanti & -0.37 & -0.77 & -1.64 & -0.93 & -0.54 & -1.68 & -1.77 & -1.33 \\
\hline Mean & -0.45 & -0.92 & -1.71 & & -0.66 & -1.76 & -1.97 & \\
\hline C.D. at $5 \%$ & $\begin{array}{l}\text { Genotypes } \\
\text { Temperatt } \\
\text { Genotypes }\end{array}$ & Temp & ature & $\begin{array}{l}=0.11 \\
=0.11 \\
=N S\end{array}$ & $\begin{array}{l}\text { Genotypes } \\
\text { Temperatv } \\
\text { Genotypes }\end{array}$ & Tempe & ture & $\begin{array}{l}=0.06 \\
=0.06 \\
=N S\end{array}$ \\
\hline
\end{tabular}


Table. 2 Changes in relative water content (RWC \%) of leaves in mungbean genotypes as affected by high temperature

\begin{tabular}{|c|c|c|c|c|c|c|c|c|}
\hline \multirow[t]{4}{*}{ Genotypes } & \multicolumn{8}{|c|}{ Relative water content (RWC \%) } \\
\hline & \multicolumn{4}{|c|}{ Normal sown } & \multicolumn{4}{|c|}{ Late sown } \\
\hline & \multirow{2}{*}{$\begin{array}{c}\begin{array}{c}\text { Control } \\
<35^{\circ}\end{array} \\
\text { Control }\end{array}$} & \multicolumn{3}{|c|}{$\begin{array}{c}>35^{\circ} \mathrm{C} \\
\text { Days of exposure (DAE) }\end{array}$} & \multicolumn{4}{|c|}{$\begin{array}{l}\quad>35^{\circ} \mathrm{C} \\
\text { Days of exposure (DAE) }\end{array}$} \\
\hline & & 3 & 7 & Mean & Control & 3 & 7 & Mean \\
\hline MH 421 & 75.83 & 71.58 & 69.79 & 72.40 & 73.34 & 70.27 & 67.41 & 70.35 \\
\hline MH 318 & 75.02 & 70.81 & 53.71 & 66.51 & 74.52 & 71.32 & 65.18 & 70.34 \\
\hline Basanti & 72.79 & 69.36 & 46.56 & 62.90 & 74.00 & 64.91 & 57.66 & 65.22 \\
\hline Mean & 74.55 & 70.58 & 56.69 & & 73.65 & 68.84 & 63.41 & \\
\hline C.D. at $5 \%$ & \multicolumn{3}{|c|}{$\begin{array}{l}\text { Genotypes } \\
\text { Temperature } \\
\text { Genotypes X Temperature }\end{array}$} & $\begin{array}{l}5.59 \\
.59 \\
9.61\end{array}$ & \multicolumn{3}{|c|}{$\begin{array}{l}\text { Genotypes } \\
\text { Temperature } \\
\text { Genotypes X Temperature } \\
\quad=2.23\end{array}$} & $\begin{array}{l}1.28 \\
.28\end{array}$ \\
\hline
\end{tabular}

Table.3 Changes in relative stress injury (RSI \%) of leaves in mungbean genotypes as affected by high temperature

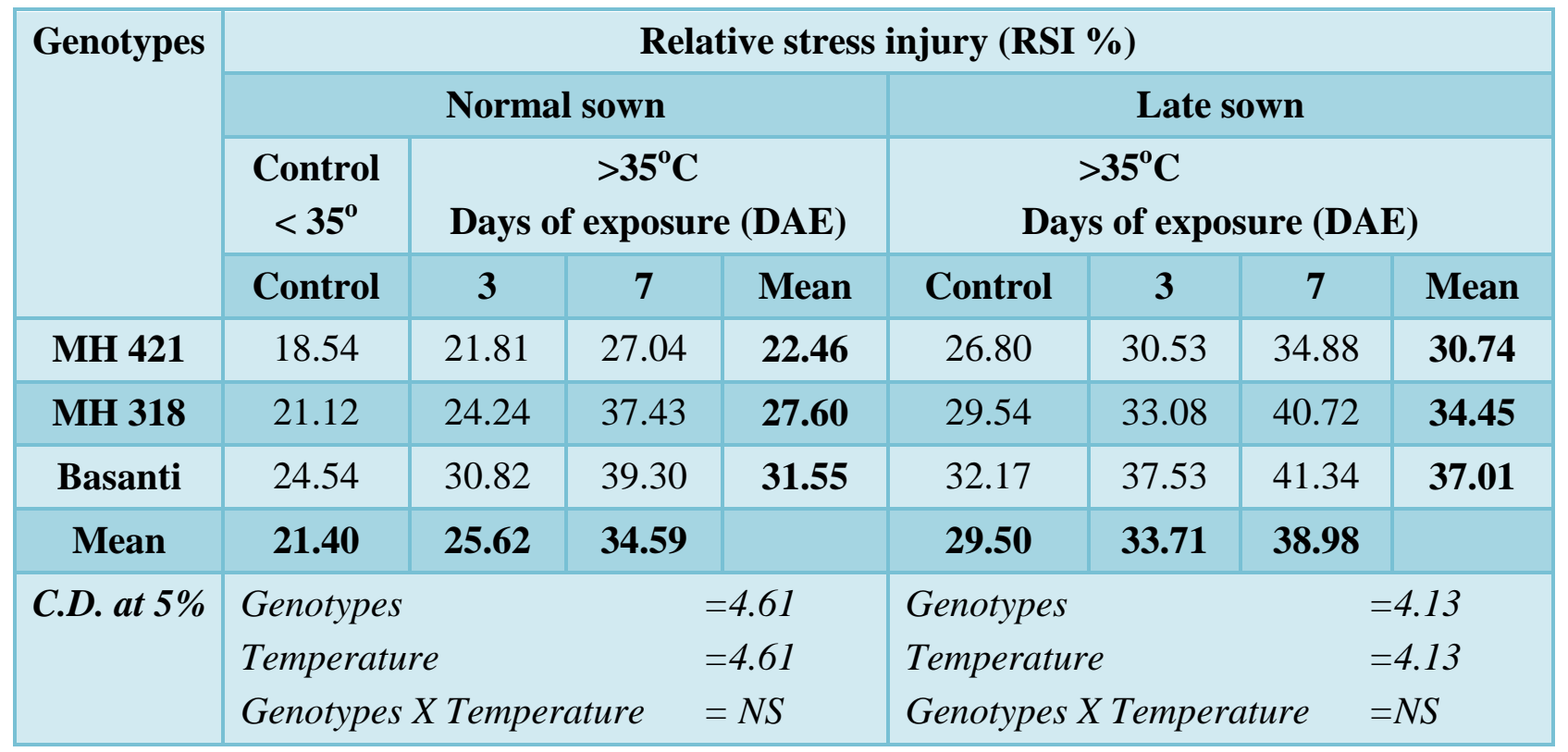


Table.4 Yield plant ${ }^{-1}$, Heat susceptibility index (HSI) and yield stability (YS) of mungbean genotypes under normal sown (NS) and late sown (LS) conditions

\begin{tabular}{|c|c|c|c|c|c|c|}
\hline \multirow[t]{2}{*}{ Genotypes } & \multicolumn{4}{|c|}{ Yield plant $^{-1}(\mathrm{~g})$} & \multirow[t]{2}{*}{ HSI } & \multirow[t]{2}{*}{ YS (\%) } \\
\hline & NS & LS & Mean & Reduction (\%) & & \\
\hline MH 421 & 3.49 & 2.74 & 3.11 & 21.5 & 0.66 & 78.51 \\
\hline MH 318 & 2.70 & 1.71 & 2.21 & 36.7 & 1.16 & 63.33 \\
\hline Basanti & 2.39 & 1.33 & 1.86 & 44.4 & 1.38 & 55.64 \\
\hline Mean & 2.86 & 1.93 & & & & \\
\hline C.D. at $5 \%$ & & & $\begin{array}{l}\text { ypes } \\
\text { rature } \\
\text { types } \times\end{array}$ & rature & $\begin{array}{l}=0.41 \\
=0.50 \\
=N S\end{array}$ & \\
\hline
\end{tabular}

Fig.1 Proline content mungbean leaves after exposure to high temperature under normal sown (NS) and late sown (LS) conditions. Vertical bars indicate \pm SE mean

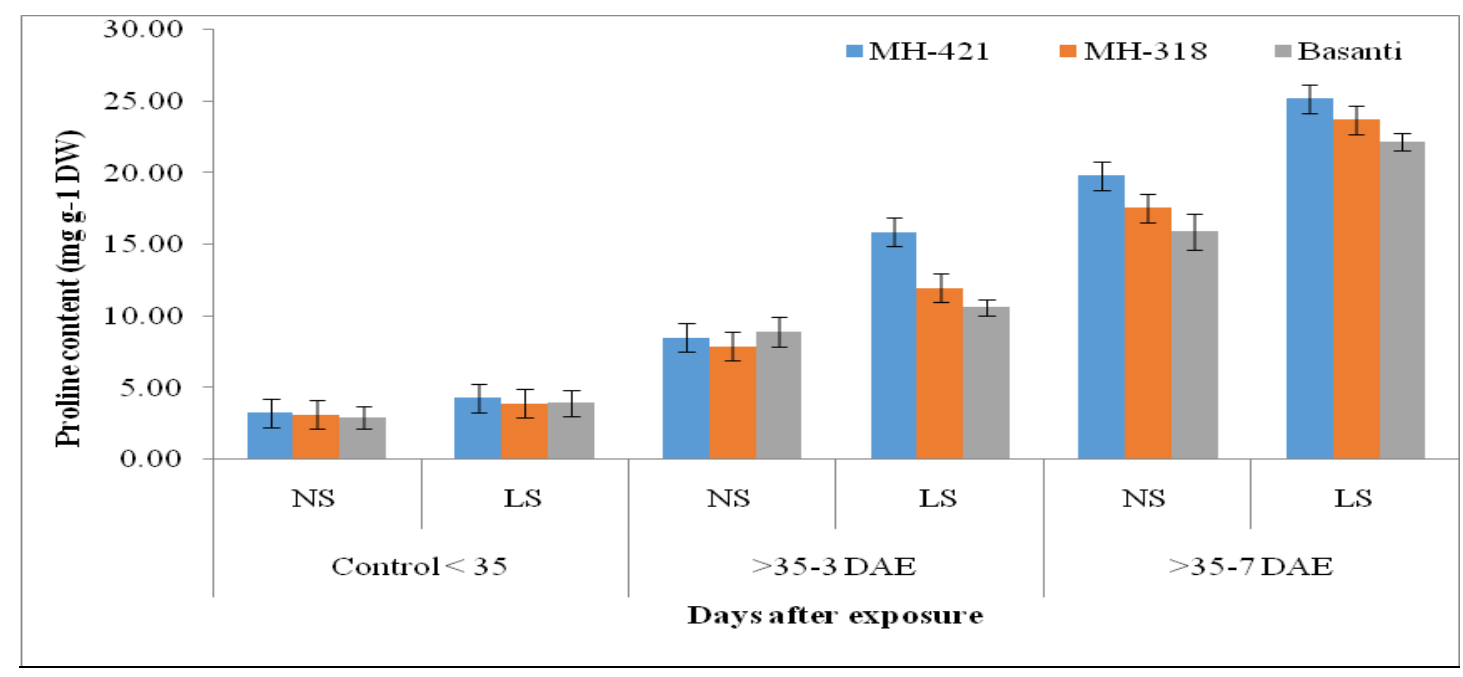

Fig.2 Total soluble carbohydrates(TSC)in mungbean leaves after exposure to high temperature under normal sown (NS) and late sown (LS) conditions. Vertical bars indicate \pm SE mean

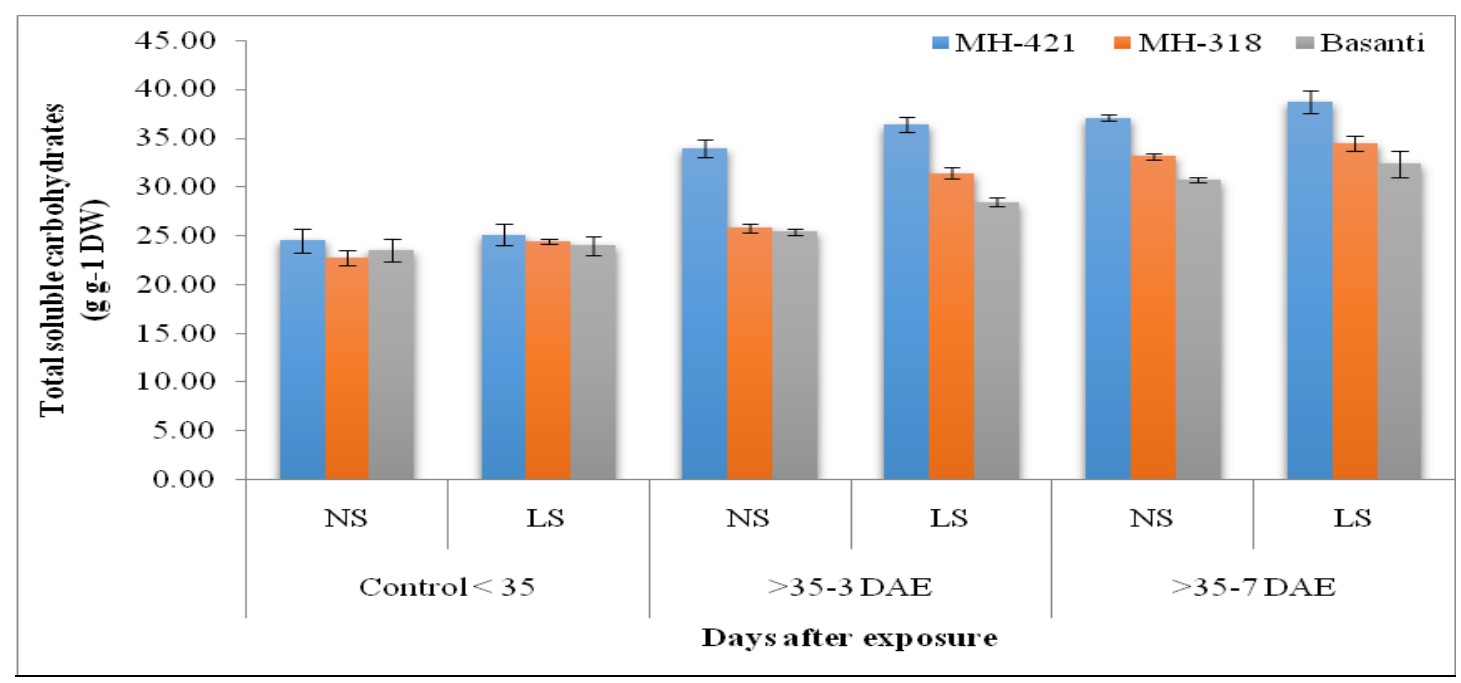


Fig.3 Malondialdehyde (MDA) content in mungbean leaves after exposure to high temperature under normal sown (NS) and late sown (LS) conditions. Vertical bars indicate \pm SE mean

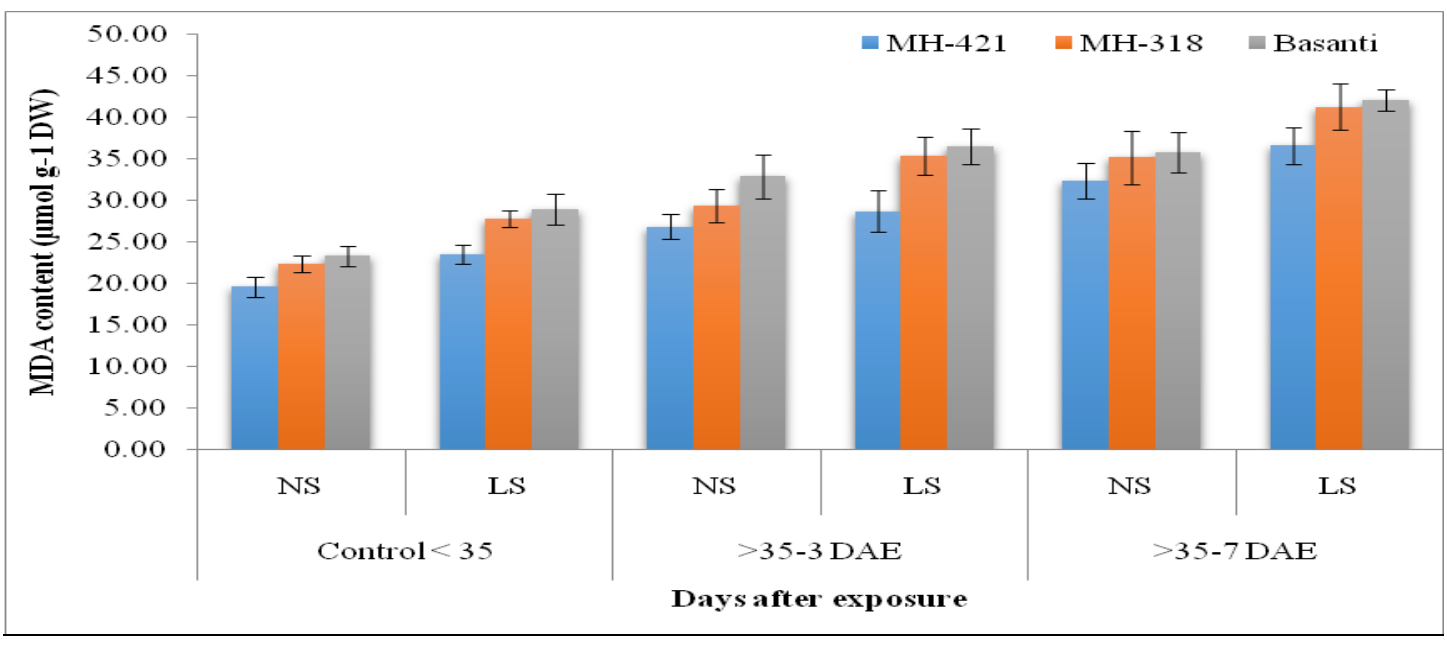

High temperature disturbs the water relations and hydraulic conductivity of roots (Morales et al., 2003). Our observations were in agreement with the earlier ones reporting reduction in RWC due to heat stress in mungbean (Sanjeev et al., 2012) and wheat (Sairam et al., 2000). Elevated temperature above $35^{\circ} \mathrm{C}$ significantly declined the water potential $\left(\Psi_{\mathrm{w}}\right)$ and relative water content (RWC) of plants. Our results showed that, in all three tested genotypes water status was affected by days after expose (DAE) to high temperature and it significantly lowered the $\Psi_{\mathrm{w}}$ of leaf (Table 1) and RWC (\%) of leaf (Table 2) in all three genotypes of mungbean at reproductive stage.

In our investigations, leakage of electrolytes (Table 3) increased significantly from leaves was observed with increase DAE to high temperature in all three genotypes. Increased leakage from tissues is usually an expression of modification in the physical properties of cell membranes. The leakage being least in leaves of $\mathrm{MH} 421$ than in Basanti and $\mathrm{MH}$ 318. The decrease in cellular respiration in heat-stressed plants is in agreement with the observations on mungbean (Sanjeev et al., 2012).
The accumulation of proline in leaves under high temperature condition at flowering stage in the genotype $\mathrm{MH} 421$ was more than $\mathrm{MH}$ 318 and Basanti (Fig. 1). Proline content increased at $35^{\circ} \mathrm{C}$ and above in this experiment is similar to the observations of (Sairam and Tyagi 2004; Zuther et al., 2007; Verbruggen and Hermanna 2008; Hossain et al., 2012). Proline can act as a signaling molecule to modulate mitochondrial functions, influence cell proliferation or cell death and trigger specific gene expression, which can be essential for plant recovery from stress (Szabados and Savoure, 2009). Proline accumulation is believed to play an adaptive role in plant stress tolerance mechanisms (Verbruggen and Hermans, 2008).

The influence of high temperature increases the total soluble carbohydrates TSC in leaves of mungbean (Fig. 2). Similar to proline, the overall accumulation of TSC was more in leaves of $\mathrm{MH} 421$ at $7 \mathrm{DAE}$ to high temperature, leading to maintenance of higher RWC and thus better plants water status. The amount of TSC increased rapidly to the increasing high temperature, this result agrees with the result of some researchers who indicated that drought (Jebory 2012,Naresh et 
al., 2013) and salinity stress induced soluble carbohydrates accumulation in chickpea (Nandwal et al., 2007; Kukreja et al., 2010).

The content of MDA (Fig.3)has been considered as an indicator of oxidative injury (Mandhania et al., 2006, Moller et al., 2007). The results of this study show that high temperature caused negative effect on growth which could be due to the generation of high levels of ROS. Plants generate ROS during growth, but the generation of ROS significantly increases when the plant is under stressful conditions (Zhang et al., 2006), which cause severe oxidative damage to different cell organelles and biomolecules (Amirjani 2012).

Reproductive duration and early maturity are the major adaptive traits for seed yield under high temperature stress. The present investigation also revealed that under late sown condition heat susceptibility index (HSI) (Table 4) and yield stability (YS) (Table 4) were 0.66, 78.51, 1.16, 63.33 and 1.38, 55.64 in $\mathrm{MH} \mathrm{421,} \mathrm{MH} 318$ and Basanti, respectively. The HSI was high in heat tolerant genotypes which have advantages in earliness and yield potential under stress. These observations support the findings of Krishnamurthy et al., (2011). The advantage of earliness and the link between pod and seed number with eventual yield under heat stress suggests that manipulation of these traits will further improve yield in warmer environments.

It is concluded that high temperature adversely affected plant water status of three genotypes. The water potential $\left(\Psi_{\mathrm{w}}\right)$ of leaf became more negative with increased period DAE to high temperature. With the increasing period of DAE, relative water content [RWC (\%)] of leaf declined significantly, whereas total soluble carbohydrates (TSC) content increased. The leakage of electrolytes form leaf tissue showed a correlation with MDA content. Based on above biochemical behavior it is concluded that MH 421 showed better performance under high temperature than MH 315 and Basanti. These results suggest that above studied characters may helpful in further selection of heat tolerance genotypes of mungbean under crop improvement programme.

\section{References}

Ali, M. and Gupta, S. 2012: Carrying capacity of Indian agriculture: pulse crops. Curr Sci.102: 874-881.

Amirjani, M. 2012. Estimation of wheat responses to "high" heat stress. Amer-Euro J. sustainable Agri. 6 (4): 222-233.

Basu, P.S., Ali, M. and Chaturvedi, S.K. 2007. Osmotic adjustment increases water uptake, remobilization of assimilates and maintains photosynthesis in chickpea under drought. Ind. J. Exp. Biol.45: 261-267.

Basu, P.S., Ali, M. and Chaturvedi, S.K. 2009. Terminal heat stress adversely affects chickpea productivity in Northern Indiastrategies to improve thermo tolerance in the crop under climate change. In: 'ISPRS Archives XXXVIII-8/W3 Workshop Proceedings: Impact of Climate Change on Agriculture'. 23-25 February, New Delhi, India. [Panigrahy, S., Shankar, S.R. and Parihar, J.S. (Eds.)]. International Society for Photogrammetry and Remote Sensing, India. 189-193.

Bates, L.S., Woldren, R.P. and Teare, I.D. 1973. Rapid determination of free proline for water stress studies. Plant Soil 39: 205-208.

Blokhina, O., Eija, V. and Kurt, V.F. 2003. Antioxidants, oxidative damage and oxygen deprivation stress: a review. Ann Bot. 91: 179-194.

Devasirvatham, V., Tan, D.K.Y., Trethowan, R.M., Gaur, P.M. and Mallikarjuna, N. 2010. Impact of high temperature on the reproductive stage of chickpea. In: 'Food security from sustainable agriculture. Proceedings of the $15^{\text {th }}$ Australian Society of Agronomy Conference' 15-18 November 2010, Lincoln, New Zealand. 
Gill, P.K., Sharma, A.D., Singh, P. and Bhullar, S.S. 2003. Changes in germination, growth and soluble sugar contents of Sorghum bicolor (L.) Moench seeds under various abiotic tresses. Plant Growth Regul. 40: 157-162

Heath, R.L. and Packer, L. 1968. Photoperoxidation in isolated chloroplasts. I. Kinetics and stoichiometry of fatty acid peroxidation. Arch. Biochem.Biophy. 125: 189-198.

Hossain, A. and Teixeira da Silva, J.A. 2012. Phenology, growth and yield of three wheat(Triticum aestivum L.) varieties as affected by high temperature stress. Not. Sci. Biol. 4 (3): 97-106.

Howarth, C.J. (2005). Genetic improvements of tolerance to high temperatures. In: Ashraf M, Harris PJC (eds) Abiotic stresses: Plant resistance through breeding and molecular approaches. Howarth Press Inc., New York.

Jebory, E.I.A. 2012. Effect of water stress on carbohydrate metabolism during Pisum sativum seedlings growth. Euphrates J. of Agri. Sci. 4(4): 1-12.

Kalra, N., Chakraborty, D., Sharma, A., Rai, H.K., Jolly, M., Chander, S., Kumar, P.R., Bhadraray, S., Barman, D., Mittal, R.B., Lal, M. and Sehgal, M. 2008. Effect of temperature on yield of some winter crops in North West India. Curr. Sci. 94: 82-88.

Kaplan, F., Kopka, J., Haskell, D.W., Zhao, W., Cameron Schiller, K.., Gatzke, N., Sung, D.Y. and Guy, C.L. 2004. Exploring the temperature stress metabolome of Arabidopsis. Plant Physiol. 136: 4159-4168

Karim, A., Hiroshi Fukamachi, H. and Hidaka, T. (2003). Photosynthetic performance of Vigna radiata L. leaves developed at different temperature and irradiance levels. Plant Science 164: 451-458.

Kempa, S., Krasensky, J., Dal Santo, S., Kopka, J. and Jonak, C. 2008. A central role of abscisic acid in stress regulated carbohydrate metabolism. PLoSOne3: e3935.

Kepova, K.D., Holzer, R., Stoilova, L.S. and Feller, U. 2005. Heat stress effects on ribulose-1,5- bisphosphate carboxylase/ oxygenase, Rubisco binding protein and rubisco activase in wheat leaves. Biol. Plant. 49: 521-525.

Krishnamurthy, L., Gaur, P.M., Basu, P.S., Chaturvedi, S.K., Tripathi, S., Vadez, V., Rathore, A.,Varshney, R.K. and Gowda, C.L.L. 2011. Large genetic variation for heat tolerance in the reference collection of chickpea (Cicer arietinum L.) germplasm. Plant Gen. Reso. 9: 59-61.

Kukreja, S., Nandwal, A.S., Kumar, N., Singh, S., Sharma, S.K., Devi, S. and Kumar, A. 2010. Ethylene evolution and modification of antioxidant defense mechanism as indices of salinity stress tolerance in Cicer arietinum L. noidules. Ind. J. Plant Physiol.15: 203-212.

Kumar, R.R., Goswami, S., Sharma, Singh, K., Gadpayle, K.A., Kumar, N., Rai, G.K., Singh, M. and Rai, R.D. 2012. Protection against heat stress in wheat involves change in cell membrane stability, antioxidant enzymes, osmolyte, $\mathrm{H}_{2} \mathrm{O}_{2}$ and transcript of heat shock protein. Int. J. Plant Physiol. Biochem. 4(4): 83-91.

Kumar, S., Kaur, R., Kaur, N., Bhandhari, K., Kaushal, N., Gupta, K., Bains, T.S. and Nayyar, H. 2011. Heat-stress induced inhibition in growth and chlorosis in mungbean (Phaseolus aureus Roxb.) is partly mitigated by ascorbic acid application and is related to reduction in oxidative stress. Acta. Physiol. Plant. 33: 2091-2101.

Lambridg, C. J. and Godwin, I. D. 2007. Genome mapping and molecular breeding in plants, pulses, sugar, and tuber crops. Heidelberg: Springer Verlag. 3: 69-90.

Larkindale, J. and Knight, M.R. 2002. Protection against heat stress induced oxidative damage in Arabidopsis involves calcium, abscisic acid, ethylene and salicylic acid, Plant Pysiol. 128: 682-695.

Mandhania, S., Madan, S. and Sawhney, V. 2006. Antioxidant defense mechanism under salt stress in wheat seedlings. Biol. Plant. 50: 227-231.

Mansoor, S. and Naqvi, F. N. 2013. Effect of heat stress on lipid peroxidation and antioxidant enzymes in mung bean (Vigna radiata $L$ ) seedlings. African J. of Biotech.12 (21): 3196-3203. 
Moller, I.M., Jensen, P.E. and Hansson, 2007. A. Oxidative modifications to cellular components in plants. Ann. Rev. Plant Biol.58: 459-481.

Morales, D., Rodriguez, P., Dell amico, J., Nicolas, E., Torrecillas, A. and SanchezBlanco, M.J. 2003. High temperature preconditioning and thermal shock imposition affects water relations, gas exchange and root hydraulic conductivity in tomato. Biol. Plant. 47: 203-208.

Nandwal, A.S., Kukreja, S., Kumar, N., Sharma, P.K., Jain, M., Mann, A. and Singh, S. 2007. Plant water status, ethylene evolution, $\mathrm{N}_{2}$-fixing efficiency, antioxidant activity and lipid peroxidation in Cicer arietinum $\mathrm{L}$. nodules as affected by shortterm salinization and desalinization. $J$. Plant. Physiol. 164: 1661-1169.

Nandwal, A.S., Kukreja, S., Kumar, N., Sharma, P.K., Jain, M., Mann, A. and Singh, S. 2007. Plant water status, ethylene evolution, $\mathrm{N}_{2}$-fixing efficiency, antioxidant activity and lipid peroxidation in Cicer arietinum L. nodules as affected by shortterm salinization and desalinization. $J$. Plant. Physiol. 164: 1661-1169.

Naresh, R.K., Purushottam, Singh, S.P., Dwivedi, A. and Kumar, V. 2013. Effects of water stress on physiological processes and yield attributes of different mungbean (L.) varieties. African J Biochem. Res.7 (5): 5562

Naresh, R.K., Purushottam, Singh, S.P., Dwivedi, A. and Kumar, V. 2013. Effects of water stress on physiological processes and yield attributes of different mungbean (L.) varieties. African J Biochem. Res.7 (5): 5562

Paulsen, G.M. 1994. High temperature responses of crop plants. In 'Physiology and determination of crop yield' [Boote, K.J. and Bennett, J.M., Sinclair, T.R. and Paulsen, G.M. (Eds.)]. (ASA, CSSA, SSSA, Madison, USA.). pp. 365-389.

Paulsen, G.M. 1994. High temperature responses of crop plants. In 'Physiology and determination of crop yield' [Boote, K.J. and Bennett, J.M., Sinclair, T.R. and Paulsen, G.M. (Eds.)]. (ASA, CSSA, SSSA, Madison, USA.). pp. 365-389.
Rizhsky, L., Liang, H., Shuman, J., Shulaev, V., Davletova, S. and Mittler, R. 2004. When defense pathways collide. The response of Arabidopsis to a combination of drought and heat stress. Plant Physiol. 134:16831696.

Rizhsky, L., Liang, H., Shuman, J., Shulaev, V., Davletova, S. and Mittler, R. 2004. When defense pathways collide. The response of Arabidopsis to a combination of drought and heat stress. Plant Physiol. 134:16831696.

Rosa, M., Prado, C., Podazza, G., Interdonato, R., González, J.A., Hilal, M. and Prado, F.E. 2009. Soluble sugars-Metabolism, sensing and abiotic stress. A complex network in the life of plants. Plant Signal. Beh.45: 388393.

Rosa, M., Prado, C., Podazza, G., Interdonato, R., González, J.A., Hilal, M. and Prado, F.E. 2009. Soluble sugars-Metabolism, sensing and abiotic stress. A complex network in the life of plants. Plant Signal. Beh.45: 388393.

Sairam, R.K. and Tyagi, A. 2004. Physiology and molecular biology of salinity stress tolerance in plants. Curr. Sci. 86: 407-421.

Sairam, R.K. and Tyagi, A. 2004. Physiology and molecular biology of salinity stress tolerance in plants. Curr. Sci. 86: 407-421.

Sairam, R.K.., Srivastava, G.C. and Saxena, D. C. 2000. Increased antioxidant activity under elevated temperatures: a mechanism of heat stress tolerance in wheat genotypes. Biol. Plant. 43: 245-251.

Sairam, R.K.., Srivastava, G.C. and Saxena, D. C. 2000. Increased antioxidant activity under elevated temperatures: a mechanism of heat stress tolerance in wheat genotypes. Biol. Plant. 43: 245-251.

Sanjeev, K., Neeru. K., Harsh. Nayyar. H and Gaur. P (2012). Abscisic acid induces heat tolerance in chickpea (Cicer arietinum L.) seedlings by facilitated accumulation of osmoprotectants. Acta Physiol Plant34:1651-1658.

Sanjeev, K., Neeru. K., Harsh. Nayyar. H and Gaur. P (2012). Abscisic acid induces heat tolerance in chickpea (Cicer arietinum L.) seedlings by facilitated accumulation of osmoprotectants. Acta Physiol 
Plant34:1651-1658.

Sung, D.Y., Kaplan, F., Lee, K.J. and Guy, C.L. (2003). Acquired tolerance to temperature extremes. Trends in Plant Science 8:179187.

Sung, D.Y., Kaplan, F., Lee, K.J. and Guy, C.L. (2003). Acquired tolerance to temperature extremes. Trends in Plant Science 8:179187.

Szabados, L. and Arnould Savoure, A. 2009. Proline: a multifunctional amino acid. Trends Plant Sci.15 (2): 89-97.

Thangwana, N.M. and Ogola, J.B.O. 2012. Yield and yield components of chickpea (Cicer arietinum): Response to genotype and planting density in summer and winter sowings. J. Food Agri. Environ.10 (2):710715.

Upadhyaya, H.D., Dronavalli, N., Gowda, C.L.L. and Singh, S. 2011. Identification and evaluation of chickpea germplasm for tolerance to heat stress. Crop Sci. 51: 20792094.

Vacca, R.A., Pinto, M.C.De., Valenti, D., Passarella, S., Maria, E. and Gara, L.De. 2004. Production of reactive oxygen species, alteration of cytosolic ascorbate peroxidase, and impairment of mitochondrial metabolism are early events in heat shock induced programmed cell death in tobacco Bright Yellow 2 cells. Plant Physiol. 134: 1100-1112.

Verbruggen, N. and Hermans, C. 2008. Proline accumulation in plants: a review. Amino
Acids35: 753-759.

Wahid, A. 2007. Physiological implications of metabolites biosynthesis in net assimilation and heat stress tolerance of sugarcane (Saccharum officinarum) sprouts. J. Plant Res.120: 219-228.

Wang, J., Gan, Y.T., Clarke, F. and McDonald, C.L. 2006. Response of chickpea yield to high temperature stress during reproductive development. Crop Sci. 46: 2171-2178.

Weatherley, P.E. 1950. Studies on the water relations of the cotton plant. The field measurement of water deficit in leaves. New Phytol. 40: 81-97.

Wilson, D.O. \& Reisenauer, H.M. (1963). Determination of leghemoglobin in legume nodules. Analytical Biochemistry, 6: 27-30.

Yemm, E.W. and Willis, A.J. (1954). The estimation of carbohydrates in plant extract by anthrone. Biochem. J. 57: 508-514.

Zhang, G.L., Chen, L.Y. and Zhang, S.T. (2006). Effect of high temperature stress on protective enzyme activities and membrane permeability of flag leaf in rice. Acta Agron. Sin. 32: 1306-1310.

Zuther, E., Koehl, K. and Kopka, J. (2007). Comparative metabolome analysis of the salt response in breeding cultivars of rice. In: Advances in molecular breeding toward drought and salt tolerant crops. [Jenks, M.A., Hasegawa, P.M. and Jain, S.M. (Eds.)] Netherlands: Springer. Pp. 285-315.

\section{How to cite this article:}

Chand, G., A. S. Nandwal, S. Dogra and Sharma, M. 2020. Biochemical Response of Mungbean [Vigna radiata (L.) Wilczek] Genotypes under Terminal Heat Stress at Reproductive Stage. Int.J.Curr.Microbiol.App.Sci. 9(07): 2975-2986. doi: https://doi.org/10.20546/ijcmas.2020.907.351 